\title{
Hungarian Language
}

National Cancer Institute

\section{Source}

National Cancer Institute. Hungarian Language. NCI Thesaurus. Code C123787.

A member of the Uralic language family that is spoken as the official language of

Hungary. 